\title{
Water-air carbon fluxes in the coastal upwelling zone off northern Baja California
}

\section{Flujos de carbono agua-aire en la zona de surgencias costeras frente al norte de Baja California}

\author{
Mauricio Alfredo Muñoz-Anderson ${ }^{1}$, José Rubén Lara-Lara ${ }^{1 *}$, Saúl Álvarez-Borrego², \\ Carmen Bazán-Guzmán ${ }^{1}$, Martín de la Cruz-Orozco ${ }^{1}$ \\ ${ }^{1}$ Departamento de Oceanografía Biológica, Centro de Investigación Científica y de Educación Superior de \\ Ensenada (CICESE), Carretera Ensenada-Tijuana 3918, Zona Playitas, Ensenada, CP 22860, Baja California, \\ México. \\ 2 Departamento de Ecología Marina, CICESE. \\ * Corresponding author. E-mail: rlara@cicese.mx
}

\begin{abstract}
An important challenge in marine science is to quantify the air-sea flux of carbon because of its possible relation to climate change and the decreasing $\mathrm{pH}$ in seawater. In coastal areas of Mexico, the magnitude and variability of carbon fluxes between the ocean and the atmosphere is almost completely unknown. Therefore, the objective of this research was to determine the variability of air-sea carbon fluxes in the upwelling system off northern Baja California. A one-year time series of carbon fluxes was generated from data on partial pressure of carbon dioxide $\left(\mathrm{pCO}_{2}\right)$ from an oceanographic buoy installed immediately south of Punta Banda (Ensenada, Baja California), which measured salinity, temperature, and $\mathrm{pCO}_{2}$ in the water $\left(\mathrm{pCO}_{2 \text { water }}\right)$ and air $\left(\mathrm{pCO}_{2 \text { air }}\right)$ every $3 \mathrm{~h}$ during 2009 . The study area presented several upwelling events with low sea surface temperatures $\left(\leq 14^{\circ} \mathrm{C}\right)$, salinity $<34.0$, and high values of $\mathrm{pCO}_{2 \text { water }}$, which resulted in an export of excess $\mathrm{CO}_{2}$ in the water to the atmosphere, identifying the area as a temporary source of $\mathrm{CO}_{2}$. In contrast, during the relaxation of upwelling, low values of $\mathrm{pCO}_{2 \text { water }}$ and intermediate surface temperatures resulted in the sea acting as a sink for $\mathrm{CO}_{2}$. The average daily flux was $0.6 \pm 0.11 \mathrm{mmol} \mathrm{C}{ }^{-2}$

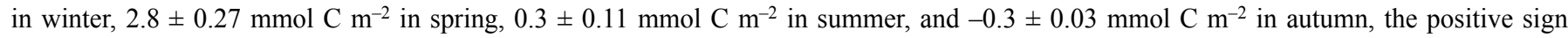
indicating fluxes from the water to the air and vice versa. The annual balance of $\mathrm{CO}_{2}$ fluxes was $0.3 \pm 0.06 \mathrm{~mol} \mathrm{C} \mathrm{m}^{-2} \mathrm{yr}^{-1}$; thus, the system turned out to be a net source of $\mathrm{CO}_{2}$ from the ocean to the atmosphere.
\end{abstract}

Key words: ocean-atmosphere carbon fluxes, coastal zone, upwelling, North Pacific.

RESUMEN. Cuantificar los flujos mar-atmósfera de carbono es un reto ambiental importante por su posible relación con el cambio climático y la disminución del pH del mar. En las zonas costeras de México se desconoce casi totalmente la magnitud y la variabilidad de los flujos de carbono entre el océano y la atmósfera. Por tal motivo, el objetivo de esta investigación fue conocer la variabilidad de los flujos de carbono en el sistema de surgencias frente a Baja California norte. Los flujos de carbono se estimaron de una serie de tiempo de la presión parcial de bióxido de carbono $\left(\mathrm{pCO}_{2}\right)$ generada a través de una boya oceanográfica instalada inmediatamente al sur de punta Banda, (Ensenada, Baja California), la cual medía salinidad, temperatura y $\mathrm{pCO}_{2}$ en el agua $\left(\mathrm{pCO}_{2 \text { agua }}\right)$ y el aire $\left(\mathrm{pCO}_{2 \text { aire }}\right)$, cada $3 \mathrm{~h}$ durante 2009 . La zona de estudio presentó varios eventos de surgencias, con temperaturas superficiales del mar bajas $\left(\leq 14{ }^{\circ} \mathrm{C}\right)$, salinidad $<34.0$ y valores altos de $\mathrm{pCO}_{2 a g u a}$, cuyo resultado fue una exportación del exceso de $\mathrm{CO}_{2}$ en el agua hacia la atmósfera, identificando dicha zona como una fuente temporal de $\mathrm{CO}_{2}$. Por el contrario, durante el relajamiento de las surgencias, se registraron valores bajos de $\mathrm{pCO}_{2 \mathrm{agua}} \mathrm{y}$ temperaturas superficiales intermedias, con el

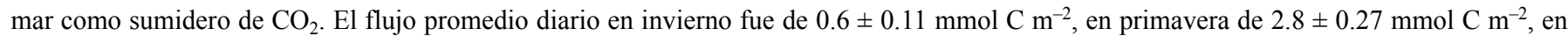
verano de $0.3 \pm 0.11 \mathrm{mmol} \mathrm{C} \mathrm{m}{ }^{-2}$ y en otoño de $-0.3 \pm 0.03 \mathrm{mmol} \mathrm{C} \mathrm{m}^{-2}$, donde el signo positivo significa flujos del agua al aire y vice versa. El balance anual de los flujos de $\mathrm{CO}_{2}$ fue de $0.3 \pm 0.06 \mathrm{~mol} \mathrm{C} \mathrm{m}^{-2}$ año-1; esto es, el sistema resultó ser una fuente neta de $\mathrm{CO}_{2}$ del océano a la atmósfera.

Palabras clave: flujos de carbono mar-atmósfera, zona costera, surgencias, Pacífico Norte.

\section{INTRODUCTION}

A topic of great concern and interest for climatologists and oceanographers is to determine how quickly natural and anthropogenic $\mathrm{CO}_{2}$ is being absorbed by the oceans. The ocean acts as a large $\mathrm{CO}_{2}$ sink (Takahashi et al. 2009), and a better understanding of the actual rate of ocean uptake of

\section{INTRODUCCIÓN}

Uno de los temas más críticos y de gran interés para climatólogos y oceanólogos es conocer qué tan rápido está siendo absorbido el $\mathrm{CO}_{2}$ natural y antropogénico por el océano. Dado que el océano es un gran sumidero de $\mathrm{CO}_{2}$ (Takahashi et al. 2009), una mejor comprensión de la actual 
$\mathrm{CO}_{2}$ is essential to reliably predict future atmospheric $\mathrm{CO}_{2}$ levels. This number, however, is difficult to define because the net air-sea $\mathrm{CO}_{2}$ flux is a small difference, of around $2 \pm 1 \mathrm{Pg} \mathrm{C} \mathrm{yr}^{-1}\left(1 \mathrm{Pg} \mathrm{C}\right.$ is $10^{15} \mathrm{~g} \mathrm{C}_{\text {in }}$ the form of $\mathrm{CO}_{2}$ ), between two large fluxes, that is, uptake and release of $\mathrm{CO}_{2}$ at the sea surface (each one approximately equal to $90 \mathrm{Pg} \mathrm{C} \mathrm{yr}^{-1}$ ) (Liu et al. 2000).

The role of coastal oceans in the global carbon budget is still under discussion, partly because sufficient data for most coastal regions are lacking. Coastal seas have high biogeochemical activity, so high fluxes of carbon between the surface water and atmosphere would be expected (Chen 2004). In general, coastal areas subject to upwelling of cold waters, rich in nutrients and dissolved inorganic carbon (DIC), are net sources of atmospheric $\mathrm{CO}_{2}$, whereas areas where upwelling is weak act as net $\mathrm{CO}_{2}$ sinks. Some coastal ecosystems (e.g., estuaries, mangrove forests, salt marshes, and coral reefs) cause the coastal oceans to be net sources of $\mathrm{CO}_{2}(\mathrm{Cai}$ et al. 2006).

Global ocean-atmosphere $\mathrm{CO}_{2}$ fluxes have been estimated using diverse methods, including hydrologic models of the carbon system in conjunction with hydrodynamic models (Arthun et al. 2012) and in situ measurements of the carbon system variables (alkalinity, DIC, $\mathrm{pH}$, and partial pressure of carbon dioxide $\left[\mathrm{pCO}_{2}\right]$ ) (Bates et al. 2011). Empirical relations have been developed between satellitederived sea surface temperatures (SST) and $\mathrm{pCO}_{2}$ in water ( $\mathrm{pCO}_{2 \text { water }}$ measured in situ) (Zirino et al. 1997, Boutin et al. 1999); between chlorophyll $a$ concentrations and $\mathrm{pCO}_{2 \text { water }}$ (Zhu et al. 2009); or between $\mathrm{pCO}_{2 \text { water }}$ chlorophyll $a$ concentrations, and SST (Chen et al. 2011). Some authors have used a combination of these methods, such as empirical relations and the compilation of available data from oceanographic cruises (Wanninkhof et al. 2012). A little more than a decade ago, however, a new technology appeared that allows realtime, high-frequency measurements of $\mathrm{pCO}_{2}$ (generating time series) by $\mathrm{pCO}_{2}$ sensors installed on oceanographic buoys (Chávez et al. 2007). It is therefore now possible to measure in real time the $\mathrm{pCO}_{2}$ in air $\left(\mathrm{pCO}_{2 \text { air }}\right)$ and $\mathrm{pCO}_{2 \text { water }}$, and subsequently estimate the carbon fluxes at different temporal scales.

In coastal areas, several processes are involved in the carbon cycle, including, among others, terrestrial runoff; upwelling events that transport subsurface water with high DIC content to the euphotic zone; photosynthesis; sinking of organic particles; respiration, production, and uptake of dissolved organic carbon; and $\mathrm{CO}_{2}$ fluxes between the atmosphere and ocean (Chávez et al. 2007). Though fluxes in coastal oceans are large relative to the surface area, there is a lack of consensus regarding whether these regions are a net sink or a net source of atmospheric $\mathrm{CO}_{2}$ (Cai and Dai 2004, Thomas et al. 2004). Uncertainties exist about the water-air carbon fluxes in coastal zones because they are complex and dynamic, and vary quickly over short distances and at high tasa de absorción oceánica de $\mathrm{CO}_{2}$ es esencial para la predicción fiable del nivel futuro de $\mathrm{CO}_{2}$ en la atmósfera. Sin embargo, este número es difícil de definir porque el flujo neto de $\mathrm{CO}_{2}$ aire-mar es una diferencia pequeña, alrededor de $2 \pm 1 \mathrm{Pg} \mathrm{C}$ año ${ }^{-1}$ ( $1 \mathrm{Pg} \mathrm{C}$ es $10^{15} \mathrm{~g} \mathrm{C}$ en la forma de $\mathrm{CO}_{2}$ ), entre dos flujos grandes, a saber, la absorción y la liberación de $\mathrm{CO}_{2}$ en la superficie del mar (cada uno aproximadamente igual a $90 \mathrm{Pg} \mathrm{C}$ año ${ }^{-1}$ ) (Liu et al. 2000).

El papel de los océanos costeros del mundo en el balance global del carbono es aún objeto de debate, en parte por no existir datos suficientes para la mayoría de las regiones costeras. Los mares costeros tienen una alta actividad biogeoquímica, por lo que se esperan flujos altos de carbono entre la superficie del agua de mar y la atmósfera (Chen 2004). En general, se ha reportado que las costas donde ocurre el afloramiento a la superficie de aguas frías, ricas en nutrientes y en carbono inorgánico disuelto (CID), son fuentes netas hacia la atmósfera, mientras que aquellas con un afloramiento débil actúan como sumideros netos de $\mathrm{CO}_{2}$. Algunos de los ecosistemas cercanos a la costa (e.g., estuarios, manglares, marismas y arrecifes de coral) causan que los océanos costeros sean una fuente neta de $\mathrm{CO}_{2}$ (Cai et al. 2006).

En escala global, la estimación del flujo de $\mathrm{CO}_{2}$ océano-atmósfera se ha llevado a cabo utilizando diversas metodologías, por ejemplo, con modelos hidrológicos del sistema del carbono en conjunto con modelos hidrodinámicos (Arthun et al. 2012) y estimaciones in situ a través de mediciones de variables del sistema del carbono (alcalinidad, $\mathrm{CID}, \mathrm{pH}$ y presión parcial del bióxido de carbono $\left[\mathrm{pCO}_{2}\right]$ ) (Bates et al. 2011). Asimismo, se han desarrollado relaciones empíricas entre la temperatura superficial del mar (TSM) medida con imágenes de satélite y la $\mathrm{pCO}_{2}$ del agua ( $\mathrm{pCO}_{\text {2agua, }}$ medida in situ) (Zirino et al. 1997, Boutin et al. 1999), o entre la concentración de clorofila $a$ y la $\mathrm{pCO}_{2 \text { agua }}$ (Zhu et al. 2009). Otros autores han desarrollado relaciones

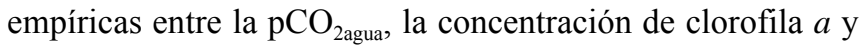
la TSM (Chen et al. 2011), o bien, la combinación de estas metodologías como las relaciones empíricas y la recopilación de datos disponibles de cruceros oceanográficos (Wanninkhof et al. 2012). Sin embargo, desde hace poco más de una década existe una tecnología que permite medir en tiempo real las variaciones de la $\mathrm{pCO}_{2}$ con alta frecuencia (generando series de tiempo) por medio de sensores de $\mathrm{pCO}_{2}$ instalados en boyas oceanográficas (Chávez et al. 2007), lo que permite medir en tiempo real la $\mathrm{pCO}_{2 \text { agua }}$ y la $\mathrm{pCO}_{2}$ del aire $\left(\mathrm{pCO}_{2 \text { aire }}\right)$, para después estimar los flujos de carbono a diferentes escalas temporales.

En la zona costera, el ciclo del carbono implica una serie de procesos, incluyendo, entre otros, el escurrimiento de los ambientes terrestres; los eventos de surgencias que acarrean aguas subsuperficiales con alto contenido de CID hacia la zona eufótica; la fotosíntesis; el hundimiento de partículas orgánicas; la respiración, la producción y el consumo de 
frequencies (Chavez et al. 2007). As mentioned above, only recently has it been possible to measure these fluxes that change rapidly, on a time scale of days, with new technologies (Friederich et al. 2002, Hales and Takahashi 2004).

In general, coastal seas have been largely ignored in global carbon budgets, although the related carbon and nutrient fluxes are disproportionately high relative to their surface area. Reports have discussed the direction, magnitude, and latitudinal variability of air-sea $\mathrm{CO}_{2}$ fluxes in marginal seas (Cai and Dai 2004, Thomas et al. 2004), but have not considered that the coastal ocean is a collection of multiple diverse ecosystems. Therefore, a climatological approach to evaluate sinks and sources of $\mathrm{CO}_{2}$ is currently not possible because of the strong temporal variation and spatial heterogeneity of coastal environments and the relatively few data available (Borges et al. 2005).

Few, sporadic measurements have been taken of the $\mathrm{CO}_{2}$ system variables in coastal waters off the Baja California Peninsula (southern part of the California Current System [CCS]). Hernández-Ayón et al. (2010) and De la CruzOrozco et al. (2010) reported data generated during oceanographic campaigns and concluded that the region of the CCS off the peninsula behaved as a minor source of atmospheric $\mathrm{CO}_{2}$. High-frequency measurements of $\mathrm{pCO}_{2}$ using oceanographic buoys equipped with sensors and telemetry were performed almost continuously throughout 2009 . The objective of this contribution is to describe the annual cycle of $\mathrm{CO}_{2}$ fluxes in a coastal upwelling zone of the southern CCS.

\section{MATERIALS AND METHODS}

\section{Study area}

The CCS is one of the most productive eastern boundary systems of the world, mainly because of the wind-induced upwelling of cold, relatively salty waters, rich in nutrients and DIC, that flow towards the euphotic zone off the coast. The hydrography off the west coast of the Baja California Peninsula (Mexico) is characterized by an equatorward surface flow, which transports relatively cold, low-salinity Subarctic Water (SAW), and by a poleward subsurface flow along the edge of the continental shelf, as well as by the occurrence of coastal upwelling events induced by northwesterly winds almost all year round (Durazo et al. 2010). Seasonally, SAW dominates in spring and summer, during the period of most intense upwelling, whereas the influence of tropical and subtropical waters is commonly felt in late summer and autumn (Lynn and Simpson 1987).

The dominant conditions of the CCS off northern Baja California are characterized by two water masses. The California Current (CC), a surface current, transports SAW, characterized by a relative salinity minimum, high dissolved oxygen levels, and a density range $\left(\sigma_{\mathrm{t}}\right)$ of 24.4 to $25.5 \mathrm{~kg} \mathrm{~m}^{-3}$ (Durazo et al. 2010). The subsurface (100-400 m depth), carbono orgánico disuelto; y los flujos de $\mathrm{CO}_{2}$ entre la atmósfera y el océano (Chávez et al. 2007). Aunque los flujos en las costas de los océanos son grandes con relación al área de la zona, no hay consenso en cuanto a si estas regiones son un sumidero neto de $\mathrm{CO}_{2}$ o una fuente neta de $\mathrm{CO}_{2}$ a la atmósfera (Cai y Dai 2004, Thomas et al. 2004). Existen incertidumbres sobre los flujos de carbono agua-aire de la zona costera, ya que son complejos y dinámicos, y varían con rapidez en distancias cortas y con frecuencias altas (Chavez et al. 2007). Tal como se mencionó anteriormente, sólo recientemente las nuevas tecnologías han permitido la medición de estos flujos que cambian rápidamente en la escala temporal de días (Friederich et al. 2002, Hales y Takahashi 2004).

En general, los mares costeros han sido en gran medida ignorados en los presupuestos globales de carbono, aunque los flujos relacionados de carbono y los nutrientes son desproporcionadamente altos en comparación con su superficie. La dirección, magnitud y variabilidad latitudinal de los flujos aire-mar de $\mathrm{CO}_{2}$ en los océanos costeros ha sido recientemente objeto de debate (Cai y Dai 2004, Thomas et al. 2004), aunque se ha pasado por alto que el océano costero es un conjunto de ecosistemas múltiples y diversos. Por lo tanto, un enfoque climatológico para evaluar los sumideros y fuentes de $\mathrm{CO}_{2}$ en el océano costero no es posible en la actualidad, debido a la fuerte variación temporal y la heterogeneidad espacial de los ambientes costeros, y a la relativa escasez de datos (Borges et al. 2005).

La medición de las variables relacionadas con el sistema del $\mathrm{CO}_{2}$ en aguas costeras frente a la península de Baja California (parte sur del Sistema de la Corriente de California [SCC]) ha sido muy escasa y esporádica. Hernández-Ayón et al. (2010) y De la Cruz-Orozco et al. (2010) reportaron información generada en campañas oceanográficas y concluyeron que la región del SCC frente a la península se comportó como fuente ligera de $\mathrm{CO}_{2}$ del océano a la atmósfera. A lo largo de 2009, se realizaron mediciones casi continuas de $\mathrm{pCO}_{2}$ a escalas de alta frecuencia, mediante boyas oceanográficas equipadas con sensores y telemetría, en la zona de surgencias costeras frente al norte de Baja California. El objetivo de esta contribución es describir el ciclo anual de los flujos de $\mathrm{CO}_{2}$ en una localidad costera en la zona de surgencias del sur del SCC donde se realizaron tales mediciones.

\section{MATERIALES Y MÉTODOS}

\section{Área de estudio}

El SCC se considera uno de los sistemas de frontera oriental más productivos del mundo, principalmente por los vientos a lo largo de la costa que generan surgencias de aguas frías, relativamente saladas, ricas en nutrientes y CID, que fluyen hacia la zona eufótica frente a la costa. La hidrografía de la región frente a la costa occidental de la península de Baja California se caracteriza por un flujo superficial hacia el 
poleward-flowing California Countercurrent transports Equatorial Subsurface Water, characterized by relatively high salinities, high nutrient and DIC concentrations, and low dissolved oxygen levels. The relatively high salinity core normally occurs over the continental slope, off the northern and central coasts of Baja California, with an isopycnal of $26.5 \mathrm{~kg} \mathrm{~m}^{-3}$ (Durazo et al. 2010). A third current some $200 \mathrm{~km}$ to the south of California has been described as an extension of the $\mathrm{CC}$, but it has not been well documented on a seasonal scale. It flows northwards along the continental shelf, and it has been associated with low temperatures at small spatial scales (20 to $50 \mathrm{~km}$ ) and with coastal cyclonic eddies (Durazo and Baumgartner 2002). This study was conducted in a coastal upwelling zone located south of Punta Banda (Ensenada), off northern Baja California, known for the seasonal variability of the oceanographic and wind conditions (Chávez de Ochoa 1975).

\section{Data acquisition}

Time series were generated by an oceanographic buoy located $\sim 3 \mathrm{~km}$ off the coast to the south of Punta Banda $\left(31.6^{\circ} \mathrm{N}, 116.6^{\circ} \mathrm{W}\right.$; fig. 1$)$. Data were recorded every $3 \mathrm{~h}$ from January to December 2009. The following variables were recorded: $\mathrm{pCO}_{2 \text { water }} \mathrm{pCO}_{2 \text { air }}$ and water temperature and salinity. As a result of sensor-related problems, $\mathrm{pCO}_{2 \text { air }}$ data were lacking for some periods and in these cases, data from the Globalview data base were used (Takahashi et al. 2009), specifically those for the station of Scripps Institution of Oceanography (University of California, San Diego). Wind speed and direction data $\left(\mathrm{u}_{10} \mathrm{~m} \mathrm{~s}^{-1}\right)$ from CICESE's meteorological station (Todos Santos Island, Baja California) were used. Temperature, salinity, and $\mathrm{pCO}_{2 \text { water }}$ were measured $1 \mathrm{~m}$ below the water surface, and $\mathrm{pCO}_{2 \text { air }}$ was measured $1 \mathrm{~m}$ above the sea surface. The sensor-equipped buoy is described in detail by Friederich et al. (2002). The sensor (LI-820) measures $\mathrm{pCO}_{2 \text { water }}$ in an air parcel in equilibrium with surface seawater by infrared absorption spectroscopy. Before this air parcel flows towards the spectrophotometer it passes through a desiccator. The sensor is calibrated before each measurement. Measurements are taken every $30 \mathrm{~min}$ and are automatically averaged every $3 \mathrm{~h}$, and the data are sent via satellite to the laboratory. Hence, the sample size for every daily average is $n=8$.

The $\mathrm{CO}_{2}$ fluxes $\left(\mathrm{FCO}_{2}\right)$ were calculated according to Sarmiento and Gruber (2006): $\mathrm{FCO}_{2}=\mathrm{KS} \Delta \mathrm{pCO}_{2}$, where $\mathrm{FCO}_{2}$ is the atmosphere-ocean flux $\left(\mu \mathrm{mol} \mathrm{m}{ }^{-2} \mathrm{~s}^{-1}\right) ; \Delta \mathrm{pCO}_{2}$ is $\mathrm{pCO}_{2 \text { water }}-\mathrm{pCO}_{2 a i r} ; \mathrm{K}$ is the gas transfer velocity, which depends on $u_{10}$ (Wanninkhof and McGillis 1999); and $\mathrm{S}$ is the solubility coefficient. The $\mathrm{FCO}_{2}$ were calculated using the 3-h data. The daily averages $\left(\mathrm{mmol} \mathrm{m}^{-2} \mathrm{~s}^{-1}\right)$ were then calculated and, finally, the net annual $\mathrm{FCO}_{2}\left(\mathrm{~mol} \mathrm{~m}^{-2} \mathrm{yr}^{-1}\right)$. ecuador, que transporta agua relativamente fría y con baja salinidad de la región subártica, y por un flujo subsuperficial hacia los polos a lo largo del borde del talud continental, así como por eventos de surgencia costera impulsados por los vientos del noroeste durante la mayor parte del año (Durazo et al. 2010). A escala estacional, el Agua Subártica (ASA) domina durante la temporada del máximo de intensidad de surgencias en la primavera y el verano, mientras que la influencia de aguas tropicales y subtropicales se observa comúnmente durante finales de verano y otoño (Lynn y Simpson 1987).

Las condiciones dominantes del SCC frente al norte de Baja California se caracterizan por dos masas de agua. La Corriente de California (CC), una corriente superficial, transporta ASA, caracterizada por un mínimo relativo de salinidad, alto contenido de oxígeno disuelto y un rango de densidad $\left(\sigma_{t}\right)$ de 24.4 a $25.5 \mathrm{~kg} \mathrm{~m}^{-3}$ (Durazo et al. 2010). La Contracorriente de California es agua subsuperficial que fluye hacia el polo ( $100 \mathrm{a} 400 \mathrm{~m}$ de profundidad) y transporta Agua Ecuatorial Subsuperficial, caracterizada por una salinidad relativamente alta, concentraciones altas de nutrientes y de CID, y un contenido bajo de oxígeno disuelto. Este núcleo de salinidad relativamente alta normalmente permanece encima del talud continental, desde la costa norte hasta la costa central de Baja California, con una isopicna de $26.5 \mathrm{~kg} \mathrm{~m}^{-3}$ (Durazo et al. 2010). Un tercer flujo alrededor de $200 \mathrm{~km}$ al sur de la costa de California se describe como una extensión de la CC. Esta corriente, que no ha sido bien documentada en escalas estacionales, fluye hacia el norte a lo largo de la plataforma continental y se asocia con temperaturas bajas en escala espacial pequeña (20 a $50 \mathrm{~km})$, con giros ciclónicos costeros (Durazo y Baumgartner 2002). Este estudio se realizó en una zona de surgencias costeras localizada al sur de punta Banda (Ensenada), frente a la costa norte de Baja California, conocida por sus condiciones oceanográficas y de viento que varían estacionalmente (Chávez de Ochoa 1975).

\section{Adquisición de datos}

Se generaron series de tiempo por medio de una boya oceanográfica situada a $\sim 3 \mathrm{~km}$ de la costa al sur de punta Banda $\left(31.6^{\circ} \mathrm{N}, 116.6^{\circ} \mathrm{W}\right.$; fig. 1$)$, con datos registrados cada $3 \mathrm{~h}$ de enero a diciembre de 2009. Las variables registradas fueron $\mathrm{pCO}_{2 a g u a}, \mathrm{pCO}_{2 \text { aire }}$, temperatura del agua y salinidad. En los periodos cuando no se tuvieron datos de $\mathrm{pCO}_{2 \text { aire }}$ por problemas con el sensor, se tomaron de la base de datos Globalview (Takahashi et al. 2009), específicamente de la estación del Instituto de Oceanografía Scripps (Universidad de California en San Diego). La magnitud y dirección del viento $\left(\mathrm{u}_{10} \mathrm{~m} \mathrm{~s}^{-1}\right)$ se tomó de la estación meteorológica del CICESE (isla de Todos Santos, Baja California). La $\mathrm{pCO}_{2 \text { aire }}$ se midió a $1 \mathrm{~m}$ por encima del nivel del mar y la $\mathrm{pCO}_{2 \text { agua }}$, así como la temperatura y salinidad, se midieron a $1 \mathrm{~m}$ por 


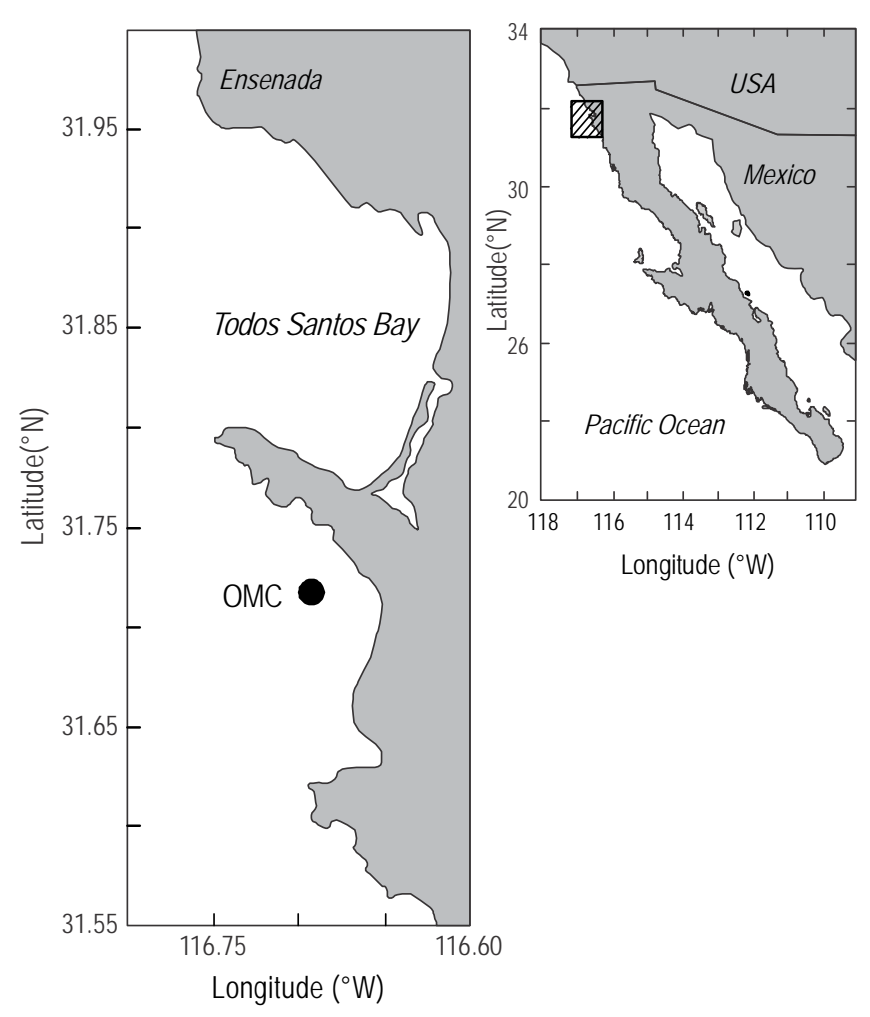

Figure 1. Study area. The oceanographic buoy was installed at the Coastal Monitoring Observatory (OMC).

Figura 1. Área de estudio. Observatorio de Monitoreo Costero $(\mathrm{OMC})$ en donde se instaló la boya oceanográfica.

\section{RESULTS}

The temperature and salinity time series (fig. 2) showed an annual mean of $15.83 \pm 0.03{ }^{\circ} \mathrm{C}$ and $33.32 \pm 0.003$, respectively (in these and all following cases, the number after \pm is the standard error, $\left.\mathrm{s} / \mathrm{n}^{-0.5}\right)$. Maximum temperature $\left(21.7^{\circ} \mathrm{C}\right)$ was recorded in summer and minimum $\left(12.0^{\circ} \mathrm{C}\right)$ in spring. Upwelling was considered to have occurred when water temperature was $<14^{\circ} \mathrm{C}$. Maximum salinity (33.65) occurred in spring and minimum (32.83) in winter. The temperature tended to increase from winter to summer and decrease in autumn. Salinity was higher in winter $(33.34 \pm 0.01)$, spring $(33.51 \pm 0.01)$, and summer $(33.31 \pm 0.01)$, and lower in autumn $(33.13 \pm 0.004)$.

Daily mean wind speed was $4.6 \pm 0.03 \mathrm{~m} \mathrm{~s}^{-1}$, with a maximum of $11.5 \mathrm{~m} \mathrm{~s}^{-1}$ and minimum of $1.0 \mathrm{~m} \mathrm{~s}^{-1}$, both in autumn (fig. 2). Wind speed tended to increase from winter to summer and decrease in autumn. Mean wind speed was $4.6 \pm 0.18 \mathrm{~m} \mathrm{~s}^{-1}$ in winter, $4.7 \pm 0.17 \mathrm{~m} \mathrm{~s}^{-1}$ in spring, $5.0 \pm$ $0.21 \mathrm{~m} \mathrm{~s}^{-1}$ (highest) in summer, and $4.2 \pm 0.19 \mathrm{~m} \mathrm{~s}^{-1}$ (lowest) in autumn.

The $\Delta \mathrm{pCO}_{2}$ time series (fig. 2) showed an annual mean of $0.2 \pm 0.99 \mu \mathrm{atm}$, with an annual maximum of $286 \mu \mathrm{atm}$ and a minimum of $-107 \mu \mathrm{atm}$, both in spring. The mean value for debajo de la superficie del mar. La boya oceanográfica equipada con los sensores es descrita en detalle por Friederich et al. (2002). El sensor (LI-820) mide la $\mathrm{pCO}_{2 \text { agua }}$ en una parcela de aire en equilibrio con el agua de mar superficial, por absorción al infrarrojo en un espectrofotómetro. Antes de que esta parcela de agua fluya hacia el espectrofotómetro pasa por un desecador. El sensor se calibra antes de cada medición. Las mediciones se registraron cada $30 \mathrm{~min}$ y se promediaron automáticamente cada $3 \mathrm{~h}$. Estos datos se enviaron vía satélite al laboratorio. Por lo tanto, cada promedio diario tiene un tamaño de muestra de $n=8$.

Los flujos de $\mathrm{CO}_{2}\left(\mathrm{FCO}_{2}\right)$ fueron calculados de acuerdo con Sarmiento y Gruber (2006): $\mathrm{FCO}_{2}=\mathrm{KS} \Delta \mathrm{pCO}_{2}$, donde $\mathrm{FCO}_{2}$ es el flujo atmosfera-océano $\left(\mu \mathrm{mol} \mathrm{m} \mathrm{m}^{-2} \mathrm{~s}^{-1}\right) ; \Delta \mathrm{pCO}_{2}$ es $\mathrm{pCO}_{\text {2agua }}-\mathrm{pCO}_{\text {2aire }} ; \mathrm{K}$ es la velocidad de transferencia del gas, que depende de $\mathrm{u}_{10}$ (Wanninkhof y McGillis 1999); y S es el coeficiente de solubilidad. Los $\mathrm{FCO}_{2}$ fueron calculados con los datos de cada $3 \mathrm{~h}$, después se calcularon los promedios diarios $\left(\mathrm{mmol} \mathrm{m}^{-2} \mathrm{~s}^{-1}\right) \mathrm{y}$, finalmente, se calculó el $\mathrm{FCO}_{2}$ neto anual $\left(\mathrm{mol} \mathrm{m}^{-2}\right.$ año $\left.^{-1}\right)$.

\section{RESUltados}

Las series de tiempo de temperatura y salinidad (fig. 2) mostraron una media anual de $15.83 \pm 0.03{ }^{\circ} \mathrm{C}$ y $33.32 \pm$ 0.003 , respectivamente (en estos casos y en los que siguen, el número a la derecha del símbolo \pm es el error estándar, $\left.\mathrm{s} / \mathrm{n}^{-0.5}\right)$. El valor máximo de temperatura $\left(21.7^{\circ} \mathrm{C}\right)$ se registró en verano y el mínimo $\left(12.0^{\circ} \mathrm{C}\right)$ en primavera. Se consideraron aguas de surgencia cuando la temperatura fue $<14{ }^{\circ} \mathrm{C}$. El valor máximo de salinidad (33.65) ocurrió en primavera y el mínimo (32.83) en invierno. La tendencia general de la temperatura fue aumentar de invierno a verano, para luego disminuir en otoño. El comportamiento de la salinidad mostró aguas de mayor salinidad en invierno, primavera y verano, con valores promedio de $33.34 \pm 0.01,33.51 \pm 0.01 \mathrm{y}$ $33.31 \pm 0.01$, respectivamente. En otoño se presentó agua de menor salinidad, con un promedio de $33.13 \pm 0.004$.

La velocidad media diaria del viento fue de $4.6 \pm$ $0.03 \mathrm{~m} \mathrm{~s}^{-1}$, con un máximo de $11.5 \mathrm{~m} \mathrm{~s}^{-1}$ y un mínimo de $1.0 \mathrm{~m} \mathrm{~s}^{-1}$, ambos en otoño (fig. 2). La tendencia general de la velocidad del viento fue incrementar de invierno a verano, y disminuir en otoño. En invierno el promedio fue de $4.6 \pm$ $0.18 \mathrm{~m} \mathrm{~s}^{-1} \mathrm{y}$ en primavera de $4.7 \pm 0.17 \mathrm{~m} \mathrm{~s}^{-1}$. En verano se presentó la mayor intensidad del viento, con una media estacional de $5.0 \pm 0.21 \mathrm{~m} \mathrm{~s}^{-1}$, y el otoño fue la estación que mostró el promedio más bajo, con $4.2 \pm 0.19 \mathrm{~m} \mathrm{~s}^{-1}$.

La serie de tiempo de $\Delta \mathrm{pCO}_{2}$ (fig. 2) mostró una media anual de $0.2 \pm 0.99 \mu \mathrm{atm}$, con un máximo anual de $286 \mu \mathrm{atm}$ y un mínimo de $-107 \mu \mathrm{atm}$, ambos en primavera. El valor promedio de primavera fue de $21.7 \pm 1.62 \mu \mathrm{atm}$. El valor promedio de verano también fue positivo, de $4.3 \pm 0.59 \mu \mathrm{atm}$, con un máximo de $132 \mu \mathrm{atm}$. El otoño presentó un promedio negativo de $-4.8 \pm 0.20 \mu \mathrm{atm}$ y menor variación, con un 
spring was $21.7 \pm 1.62 \mu \mathrm{atm}$. The mean value for summer was also positive, $4.3 \pm 0.59 \mu \mathrm{atm}$, and the maximum value was $132 \mu \mathrm{atm}$. The mean value for autumn was negative, $-4.8 \pm 0.20 \mu \mathrm{atm}$; the autumn values showed less variation, ranging from a minimum of $-50.0 \mu \mathrm{atm}$ to a maximum of $17.1 \mu \mathrm{atm}$, the smallest range of all the year (of $67 \mu \mathrm{atm}$ ). Winter showed a similar behavior to that of spring, with a mean $\Delta \mathrm{pCO}_{2}$ value of $15.0 \pm 0.82 \mu \mathrm{atm}$; the winter positive values mainly occurred in March (maximum of $127 \mu \mathrm{atm}$ ). The maximum and minimum values for summer and winter were very similar (fig. 2).

The $\mathrm{CO}_{2}$ fluxes showed strong variability throughout 2009 (fig. 2). The mean winter $\mathrm{CO}_{2}$ flux was $0.6 \pm 0.11 \mathrm{mmol}$ $\mathrm{C} \mathrm{m}^{-2} \mathrm{~d}^{-1}$. The lowest $\mathrm{CO}_{2}$ flux of the year occurred in

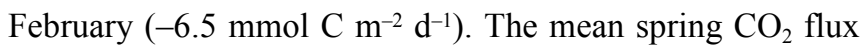
was $2.8 \pm 0.27 \mathrm{mmol} \mathrm{C} \mathrm{m}^{-2} \mathrm{~d}^{-1}$, the highest of the year; spring had the highest single value of the year $\left(27.1 \mathrm{mmol} \mathrm{C} \mathrm{m}^{-2} \mathrm{~d}^{-1}\right)$ and a minimum value of $-4.3 \mathrm{mmol} \mathrm{C} \mathrm{m}^{-2} \mathrm{~d}^{-1}$. The mean summer $\mathrm{CO}_{2}$ flux was $0.3 \pm 0.11 \mathrm{mmol} \mathrm{C} \mathrm{m} \mathrm{C} \mathrm{d}^{-1}$, and the minimum and maximum values were -5.2 and $11.9 \mathrm{mmol} \mathrm{C}$ $\mathrm{m}^{-2} \mathrm{~d}^{-1}$, respectively. The mean value for autumn was negative, $-0.3 \pm 0.03 \mathrm{mmol} \mathrm{C} \mathrm{m}^{-2} \mathrm{~d}^{-1}$, indicating a flux from the atmosphere to the ocean, and the minimum and maximum values were -4.2 and $3.4 \mathrm{mmol} \mathrm{C} \mathrm{m}^{-2} \mathrm{~d}^{-1}$, respectively. The mean annual $\mathrm{CO}_{2}$ flux was $0.9 \pm 0.16 \mathrm{mmol} \mathrm{C} \mathrm{m} \mathrm{C} \mathrm{d}^{-1}$. The annual balance of $\mathrm{CO}_{2}$ fluxes was $0.3 \pm 0.06 \mathrm{~mol} \mathrm{C} \mathrm{m}^{-2} \mathrm{yr}^{-1}$.

\section{DISCUSSION}

Our time series clearly show the influence of coastal upwelling on $\mathrm{CO}_{2}$ fluxes to the atmosphere (fig. 2). Below the euphotic zone, respiration increases DIC and nutrients such as $\mathrm{NO}_{3}$, presumably following the Redfield ratios; however, respiration is not the only process that affects DIC and $\mathrm{NO}_{3}$. The presence of excess DIC relative to $\mathrm{NO}_{3}$ has been attributed to the dissolution of calcium carbonate exoskeletons at depth (Park 1965), to denitrification processes associated with the oxygen minimum zone in the eastern Pacific (Thomas 1966), and to differences in preformed DIC (Park 1965). Denitrification and calcium carbonate dissolution processes occur along the trajectory of the water masses, from their origin at high latitudes, and not only locally off Baja California. When water rises to the euphotic zone and photosynthesis consumes nutrients such as $\mathrm{NO}_{3}$ there is an excess of $\mathrm{CO}_{2}$ that escapes to the atmosphere (RodríguezIbáñez et al. 2013).

Álvarez-Borrego and Álvarez-Borrego (1982) reported that upwelling events off Baja California are a sequence of intensifications and relaxations with periods of about two weeks. These authors reported the occurrence of ten intense events in 1979 at a site located $200 \mathrm{~km}$ south of Ensenada, the most intense in July when minimum surface temperatures were $<11.0^{\circ} \mathrm{C}$. The annual $\mathrm{CO}_{2}$ flux time series (fig. 2) showed four periods of ocean-to-atmosphere $\mathrm{CO}_{2}$ fluxes mínimo de $-50.0 \mu$ atm y un máximo de $17.1 \mu$ atm, siendo éste el intervalo más pequeño de todo el año (de $67 \mu \mathrm{atm}$ ). El invierno mostró un comportamiento similar al de primavera, con un promedio de $\Delta \mathrm{pCO}_{2}$ de $15.0 \pm 0.82 \mu \mathrm{atm}$; los valores positivos de invierno se registraron fundamentalmente en marzo con un máximo de $127 \mu \mathrm{atm}$. Los valores máximos y mínimos de verano e invierno fueron muy similares (fig. 2).

Los flujos de $\mathrm{CO}_{2}$ presentaron una variabilidad fuerte durante todo el año (fig.2). En invierno el flujo promedio fue de $0.6 \pm 0.11 \mathrm{mmol} \mathrm{C} \mathrm{m}^{-2} \mathrm{~d}^{-1}$. El valor más bajo de flujo de $\mathrm{CO}_{2}$ del año ocurrió en febrero $\left(-6.5 \mathrm{mmol} \mathrm{C} \mathrm{m}^{-2} \mathrm{~d}^{-1}\right)$. La primavera mostró el valor promedio más alto registrado en 2009 , de $2.8 \pm 0.27 \mathrm{mmol} \mathrm{C} \mathrm{m}^{-2} \mathrm{~d}^{-1}$, así como el valor más alto del año $\left(27.1 \mathrm{mmol} \mathrm{C} \mathrm{m}^{-2} \mathrm{~d}^{-1}\right)$ y un mínimo de $-4.3 \mathrm{mmol} \mathrm{C} \mathrm{m}{ }^{-2} \mathrm{~d}^{-1}$. En verano el flujo promedio fue de $0.3 \pm 0.11 \mathrm{mmol} \mathrm{C} \mathrm{m}^{-2} \mathrm{~d}^{-1}$, con un mínimo de $-5.2 \mathrm{mmol} \mathrm{C}$

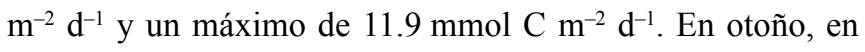
promedio el flujo fue negativo, de la atmósfera al océano, con un valor promedio de $-0.3 \pm 0.03 \mathrm{mmol} \mathrm{C} \mathrm{m}^{-2} \mathrm{~d}^{-1}$, un valor mínimo de $-4.2 \mathrm{mmol} \mathrm{C} \mathrm{m}^{-2} \mathrm{~d}^{-1}$ y un valor máximo de $3.4 \mathrm{mmol} \mathrm{C} \mathrm{m} \mathrm{d}^{-1}$. El flujo promedio anual de $\mathrm{CO}_{2}$ fue de $0.9 \pm 0.16 \mathrm{mmol} \mathrm{C} \mathrm{m}^{-2} \mathrm{~d}^{-1}$. El balance anual de los flujos de $\mathrm{CO}_{2}$ fue $0.3 \pm 0.06 \mathrm{~mol} \mathrm{C} \mathrm{m}^{-2}$ año $^{-1}$.

\section{DiscuSIón}

La influencia de las surgencias costeras en los flujos de $\mathrm{CO}_{2}$ hacia la atmósfera es muy clara en nuestras series de tiempo (fig. 2). Por debajo de la zona eufótica la respiración aumenta el CID y nutrientes como el $\mathrm{NO}_{3}$, presumiblemente siguiendo las razones de Redfield, pero la respiración no es el único proceso que afecta al CID y $\mathrm{NO}_{3}$. Un exceso de CID en relación con $\mathrm{NO}_{3}$ ha sido atribuido a la disolución de exoesqueletos de carbonato de calcio a profundidad (Park 1965), a procesos de desnitrificación asociados con la zona del mínimo de oxígeno en el Pacífico oriental (Thomas 1966) y a diferencias en el CID preformado (Park 1965). Los procesos de disolución de carbonato de calcio y de desnitrificación ocurren a lo largo de la trayectoria de las masas de agua desde su origen en latitudes elevadas y no sólo localmente frente a Baja California. Cuando el agua surge hasta la zona eufótica, y la fotosíntesis consume nutrientes como el $\mathrm{NO}_{3}$, queda un exceso de $\mathrm{CO}_{2}$ que termina fugándose a la atmósfera (Rodríguez-Ibáñez et al. 2013).

Álvarez-Borrego y Álvarez-Borrego (1982) reportaron que los eventos de surgencia frente al norte de Baja California se dan como una secuencia de intensificaciones y relajamientos, con periodo cercano a dos semanas. Estos autores reportaron diez eventos intensos en 1979 en una localidad a $200 \mathrm{~km}$ al sur de Ensenada, el más intenso en julio con temperaturas superficiales mínimas de $<11.0^{\circ} \mathrm{C}$. La serie de tiempo de los flujos de $\mathrm{CO}_{2}$ (fig. 2) mostró cuatro periodos de flujos del océano hacia la atmósfera con eventos de intensificación de surgencias $\left(\mathrm{TSM}<14{ }^{\circ} \mathrm{C}\right)$. En el primer periodo 

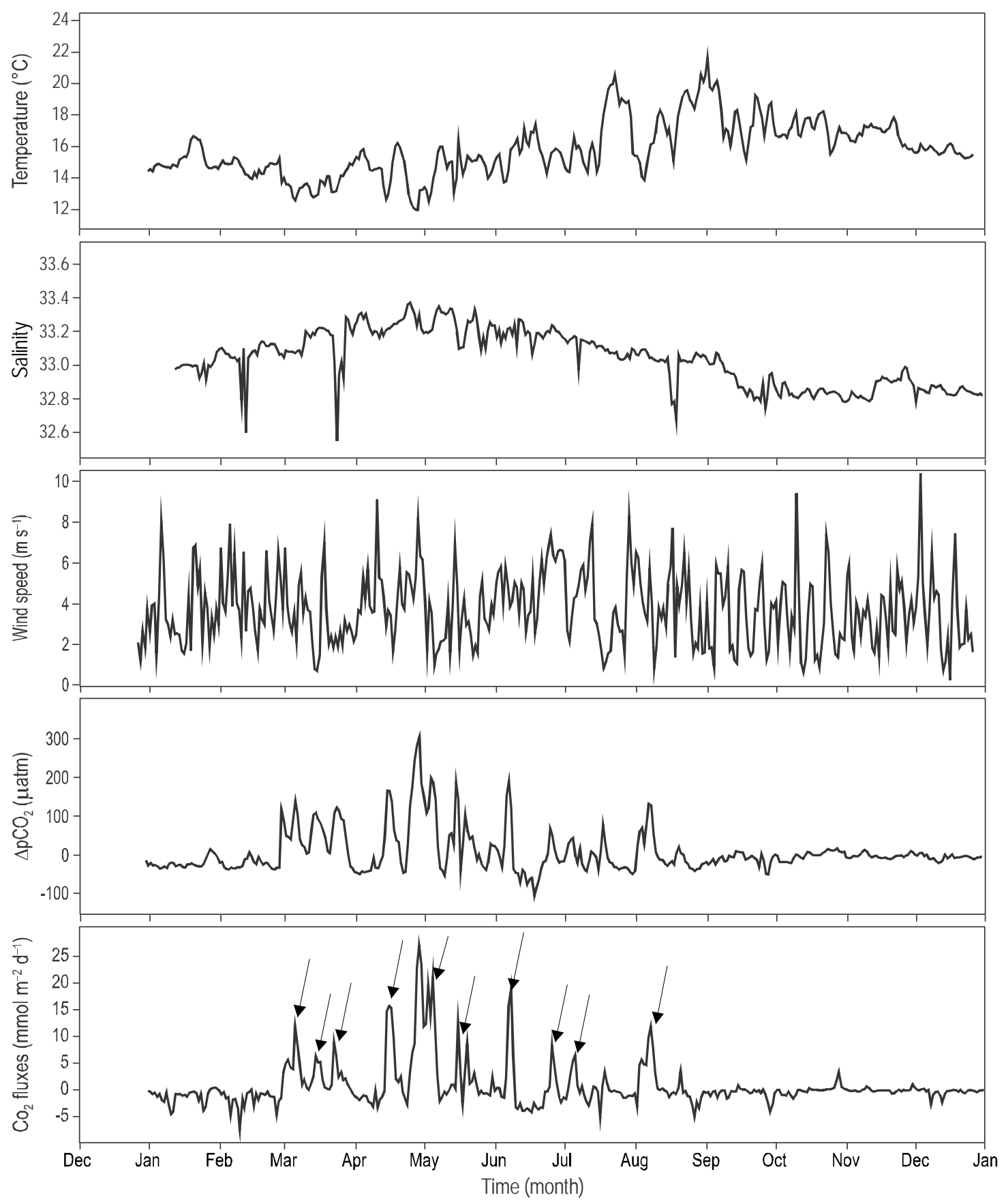

Figure 2. Time series of temperature $\left({ }^{\circ} \mathrm{C}\right)$, salinity, wind speed $\left(\mathrm{m} \mathrm{s}^{-1}\right), \Delta \mathrm{pCO}_{2}(\mu \mathrm{atm})$, and $\mathrm{CO}_{2}$ fluxes $\left(\mathrm{mmol} \mathrm{m}^{-2} \mathrm{~d}^{-1}\right)$ for the study site, during 2009. The arrows indicate the most intense upwelling events of the year.

Figura 2. Series de tiempo de temperatura $\left({ }^{\circ} \mathrm{C}\right)$, salinidad, velocidad del viento $\left(\mathrm{m} \mathrm{s}^{-1}\right), \Delta \mathrm{pCO}_{2}(\mu \mathrm{atm})$ y flujos de $\mathrm{CO}_{2}\left(\mathrm{mmol} \mathrm{m}^{-2} \mathrm{~d}^{-1}\right)$ para el sitio de estudio, durante 2009. Las flechas indican los eventos de surgencia más intensos del año. 
during which upwelling intensification events $\left(\mathrm{SST}<14^{\circ} \mathrm{C}\right)$ occurred. Three events occurred during the first period (March), the first from 1 to 8 March, the second from 14 to 16 March, and the third on 20 March, with fluxes of 11.7, 6.4, and $\sim 8 \mathrm{mmol} \mathrm{C} \mathrm{m}^{-2} \mathrm{~d}^{-1}$, respectively. Four events occurred during the second period (April to June), which was the most intense of the year, the first around 15 April, the second between 22 and 30 April, the third between 14 and 16 May, and the fourth on 2 June, with fluxes of up to 15.7, 27, 8.5, and $18 \mathrm{mmol} \mathrm{C} \mathrm{m} \mathrm{d}^{-1}$, respectively. One event occurred during the third period, from 25 June to 3 July, and one event occurred during the fourth period, from 3 to 10 August, with fluxes of up to 8.4 and $11.2 \mathrm{mmol} \mathrm{C} \mathrm{m}^{-2} \mathrm{~d}^{-1}$, respectively (fig. 2).

Upwelling systems are characterized by high primary production rates and are thus important sites for carbon fluxes across the continental margin; that is, there will be large fluxes of particulate organic carbon from the euphotic zone to the bottom. Coastal upwelling zones show oversaturation of $\mathrm{CO}_{2}$ with respect to atmospheric equilibrium due to the input of deep, DIC-rich waters (Rodríguez-Ibáñez et al. 2013). Nutrient inputs increase primary production, which in turn reduces the $\mathrm{pCO}_{2}$ values. These two processes have opposite effects on $\mathrm{pCO}_{2}$ (Borges et al. 2005). For example, very high oversaturation of $\mathrm{CO}_{2}$ with respect to the atmosphere (up to $1200 \mu \mathrm{atm}$ ) has been reported for coastal upwelling systems off Peru and Chile, known to be one of the most productive areas worldwide (Torres et al. 2002). The range of variation is smaller $(100-800 \mu \mathrm{atm})$ for other upwelling systems, such as off the coast of California (Friederich et al. 2002).

Based on the few available estimates of annual $\mathrm{CO}_{2}$ fluxes for marginal seas, Borges et al. (2005) reported that areas with high upwelling index values, such as the coasts of California and Oman (Arabian Sea), tend to be sources of $\mathrm{CO}_{2}$, whereas regions with low upwelling index values, such as the Galician coast (Spain) and Vancouver Island (Canada), tend to be sinks of $\mathrm{CO}_{2}$.

On a large scale, the hydrographic conditions in our study area are influenced by changes in the CCS and, therefore, by seasonal and interannual variations (El Niño/La Niña), which are typical in this region of the Pacific (Linacre et al. 2010). During our study period, surface temperature and salinity values were within the range of values for SAW, characterized by temperatures of $8-22{ }^{\circ} \mathrm{C}$ and salinities of $33-34$ (Durazo and Baumgartner 2002).

In our study area, during spring and summer, the main physical process that modified the hydrographic conditions near the shore was upwelling driven by the alongshore component of strong winds $\left(>7.5 \mathrm{~m} \mathrm{~s}^{-1}\right)$, resulting in the presence of relatively saltier, colder $\left(<14^{\circ} \mathrm{C}\right)$ surface water, rich in nutrients (Lara-Lara et al. 1980) and DIC, associated with high $\mathrm{pCO}_{2}$ values. Variability during summer and autumn and during winter and spring is mainly associated (marzo) se observan tres eventos muy claros: el primer evento ocurrió del 1 al 8 de marzo, con flujos de hasta $11.7 \mathrm{mmol} \mathrm{C} \mathrm{m}^{-2} \mathrm{~d}^{-1}$; el segundo entre el 14 y 16 de marzo, con flujos de hasta $6.4 \mathrm{mmol} \mathrm{C} \mathrm{m}^{-2} \mathrm{~d}^{-1}$; y el tercero el $20 \mathrm{de}$

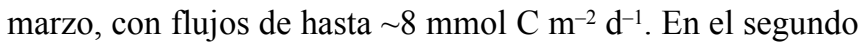
periodo (abril a junio), el más intenso de todo el año, se observan cuatro eventos, el primero alrededor del 15 de abril, con flujos de hasta $15.7 \mathrm{mmol} \mathrm{C} \mathrm{m}^{-2} \mathrm{~d}^{-1}$; el segundo entre el 22 y 30 de abril, con flujos de hasta $27 \mathrm{mmol} \mathrm{C} \mathrm{m}^{-2} \mathrm{~d}^{-1}$; el tercero del 14 al 16 de mayo, con flujos de hasta $8.5 \mathrm{mmol} \mathrm{C}$ $\mathrm{m}^{-2} \mathrm{~d}^{-1}$; y el cuarto el 2 de junio, con flujos de hasta $18 \mathrm{mmol}$ $\mathrm{C} \mathrm{m}^{-2} \mathrm{~d}^{-1}$. En el tercer periodo se observa un evento, del $25 \mathrm{de}$ junio al 3 de julio, con flujos de hasta $8.4 \mathrm{mmol} \mathrm{C} \mathrm{m}^{-2} \mathrm{~d}^{-1}, \mathrm{y}$ en el último periodo también se observa un evento, del 3 al 10 de agosto, con valores máximos de $11.2 \mathrm{mmol} \mathrm{C} \mathrm{m}^{-2} \mathrm{~d}^{-1}$ (fig. 2).

Los sistemas de surgencia se caracterizan por las altas tasas de producción primaria, por lo que estas áreas son sitios importantes para los flujos de carbono en todo el margen de la plataforma continental; es decir, de cualquier forma tienen flujos grandes de carbono orgánico particulado de la zona eufótica al fondo. Estas zonas de afloramiento costero son conocidas por mostrar sobresaturación de $\mathrm{CO}_{2}$ con respecto al equilibrio atmosférico debido a la entrada de aguas profundas ricas en CID (Rodríguez-Ibáñez et al. 2013). El aporte de nutrientes provee el combustible para elevar la producción primaria que a su vez reduce los valores de $\mathrm{pCO}_{2}$. Estos dos procesos tienen efectos opuestos sobre la $\mathrm{pCO}_{2}$ (Borges et al. 2005). Por ejemplo, para los sistemas de surgencia costera de Perú y Chile, que son conocidos por estar entre las áreas oceánicas más productivas de todo el mundo, se ha reportado sobresaturación muy elevada de $\mathrm{CO}_{2}$ (hasta $1200 \mu \mathrm{atm}$ ) con respecto a la atmósfera (Torres et al. 2002). Otros sistemas de afloramiento muestran un menor rango de variación (100-800 $\mu \mathrm{atm})$, por ejemplo la costa de California (Friederich et al. 2002).

Con base en las pocas estimaciones que se han realizado sobre los flujos anuales de $\mathrm{CO}_{2}$ en la zona costera, Borges et al. (2005) encontraron que las áreas con valores altos del índice de surgencia, tales como las de las costas de California y de Omán (mar Arábigo), tienden a ser fuentes de $\mathrm{CO}_{2}$, a diferencia de las áreas con valores bajos del índice de surgencia que tienden a ser sumideros de $\mathrm{CO}_{2}$, tales como las localizadas frente a las costas de Galicia (España) y la isla de Vancouver (Canadá).

A gran escala, las condiciones hidrográficas de nuestra área de estudio son influenciadas por los cambios en el SCC $\mathrm{y}$, por lo tanto, afectadas por las variaciones estacionales e interanuales (El Niño/La Niña), las cuales son típicas de esta región del Pacifico (Linacre et al. 2010). Durante nuestro periodo de estudio, la temperatura superficial y la salinidad estuvieron dentro del rango de ASA, la cual se caracteriza por temperaturas entre 8 y $22{ }^{\circ} \mathrm{C}$ y salinidades de 33 a 34 (Durazo y Baumgartner 2002). 
with the circulation patterns off California and northern Baja California, such as the poleward surface flow and intense mesoscale activity (Durazo et al. 2010).

Durazo et al. (2010) mention that in the region off northern Baja California, upwelling occurs throughout the year but with greater intensity in spring and summer. Our findings clearly show significant differences between the water-air $\mathrm{CO}_{2}$ fluxes estimated for spring/summer and autumn/winter. Lynn and Simpson (1987) observed that the CC intensifies in spring and summer due to norwesterly winds, which generate intense upwelling events. In early autumn, wind speeds decline and coastal upwelling weakens. In late autumn and early winter, the surface coastal countercurrent appears and inhibits upwelling (Hickey 1979).

The data obtained in the present study suggest that the variability of the $\mathrm{CO}_{2}$ fluxes at the buoy location can be divided into two periods. During spring and summer (March-August), when upwelling events predominated, the system acted as a source of $\mathrm{CO}_{2}$ to the atmosphere. Conversely, during autumn and winter (September-December), when the upwelling events weakened, the system acted as a sink of atmospheric $\mathrm{CO}_{2}$. These results differ from those obtained by Hernández-Ayón et al. (2010) for the entire CCS off Baja California, including the oceanic zone. These authors reported, on average, $\mathrm{CO}_{2}$ fluxes from the atmosphere to the ocean in winter and spring, and fluxes from the ocean to the atmosphere in summer and autumn. An explanation for these differences could be that their averages included measurements for oceanic waters and were not only affected by local physical processes occuring near the shore, such as upwelling. Strictly speaking, the comparison of our results with those of Hernández-Ayón et al. (2010) is not appropriate because the spatial and temporal scales are entirely different.

According to Pennington et al. (2010), two scenarios can be distinguished in coastal areas of the northwestern Pacific where upwelling events occur. In the first scenario, the water DIC concentration is high associated with relatively low surface temperatures $\left(\leq 13.0^{\circ} \mathrm{C}\right)$, salinity close to 34 , and high $\mathrm{pCO}_{2}$ values $(>500 \mu \mathrm{atm})$. These conditions coincide with those found in this study, since the highest $\mathrm{pCO}_{2}$ values and $\mathrm{CO}_{2}$ fluxes were recorded in spring when the temperature was lowest $\left(\leq 14{ }^{\circ} \mathrm{C}\right)$ and salinity was close to 34 . These conditions occur because, in our study area, the core of the $\mathrm{CC}$, which transports low salinity $(<34)$ SAW towards the equator, is located close to shore in spring (Linacre 2010). Durazo et al. (2010) reported that SAW was the only water mass recorded off Ensenada in 2009. The influence of SAW is maximum in spring, during the upwelling season when northwesterly winds predominate in the region (Pérez-Brunius et al. 2007). In the second scenario, the coastal area can be neutral or act as a weak sink. In our study area, the system acted as a sink between September and January.

Chávez et al. (2007) observed that, on an annual basis, the Pacific coasts and areas close to $30^{\circ} \mathrm{N}$ latitude tend to act
En nuestra región de estudio, durante primavera y verano, el proceso físico principal que modificó las condiciones hidrográficas cerca de la costa fue la surgencia provocada por vientos fuertes $\left(>7.5 \mathrm{~m} \mathrm{~s}^{-1}\right)$ con componente a lo largo de la costa, lo cual se traduce en la presencia de agua superficial relativamente más salada, más fría $\left(<14{ }^{\circ} \mathrm{C}\right)$ y ricas en nutrientes (Lara-Lara et al. 1980) y en CID, por supuesto asociado a valores altos de $\mathrm{pCO}_{2}$. La variabilidad durante verano y otoño y durante invierno y primavera se da básicamente por los patrones de circulación frente al sur de California y el norte de Baja California, como la actividad intensa de mesoescala y el flujo superficial hacia el polo (Durazo et al. 2010).

Durazo et al. (2010) mencionan que en la región frente al norte de Baja California las surgencias persisten todo el año, pero con mayor intensidad en primavera y verano. Los resultados obtenidos en nuestro estudio muestran claramente las diferencias significativas de los flujos agua-aire de $\mathrm{CO}_{2}$ estimados para primavera y verano y para otoño e invierno. Lynn y Simpson (1987) mencionan que la CC se intensifica en primavera y verano debido a los vientos del noroeste, los cuales la impulsan y generan eventos intensos de surgencias costeras. A principios de otoño los vientos disminuyen debilitando los afloramientos costeros. A finales de otoño y principios de invierno se manifiesta la contracorriente costera superficial que inhibe las surgencias (Hickey 1979).

Los datos obtenidos en este estudio sugieren que la variabilidad de los flujos de $\mathrm{CO}_{2}$ en la localidad de la boya se puede dividir en dos periodos. Durante el primero, en primavera y verano (marzo-agosto), el sistema se comportó como fuente de $\mathrm{CO}_{2}$ del océano a la atmosfera; durante este periodo dominaron los eventos de surgencia. Por el contrario, durante el segundo periodo, en otoño e invierno (septiembre-diciembre), el sistema se comportó como un sumidero de $\mathrm{CO}_{2}$, esto es, el flujo fue de la atmósfera al océano; durante este periodo hubo un relajamiento de los eventos de surgencias. Estos resultados difieren de lo reportado por Hernández-Ayón et al. (2010) para toda la zona del SCC frente a Baja California, incluyendo la zona oceánica. Estos autores observaron, en promedio, un flujo de la atmósfera hacia el océano en invierno y primavera, y un flujo de $\mathrm{CO}_{2}$ hacia la atmósfera en verano y otoño. Estas diferencias podrían deberse a que sus promedios incluyeron mediciones en aguas oceánicas y no sólo tuvieron la influencia de los procesos físicos locales que se presentan cerca de la costa, como las surgencias. En sentido estricto, la comparación de nuestros resultados con los de Hernández-Ayón et al. (2010) no es apropiada porque las escalas temporales y espaciales son totalmente diferentes.

De acuerdo con Pennington et al. (2010) se pueden distinguir dos escenarios en las zonas costeras donde se presentan eventos de surgencia en el Pacífico nororiental. En el primer escenario se presentan aguas con CID alto asociado con una temperatura superficial relativamente baja $\left(\leq 13.0^{\circ} \mathrm{C}\right)$, salinidad cercana a 34 y valores altos de $\mathrm{pCO}_{2}(>500 \mu \mathrm{atm})$. Estas condiciones coinciden con lo registrado en nuestro estudio, 
as a source of $\mathrm{CO}_{2}$ to the atmosphere, whereas areas above $40^{\circ} \mathrm{N}$ tend to be sinks. For waters off the Baja California Peninsula, De la Cruz-Orozco et al. (2010) reported a net annual flux of $0.41 \mathrm{~mol} \mathrm{C} \mathrm{m}^{-2} \mathrm{yr}^{-1}$ and Hernández-Ayón et al. (2010) reported, based on historical $\mathrm{pCO}_{2}$ data, a net annual flux of $0.97 \mathrm{~mol} \mathrm{C} \mathrm{m}^{-2} \mathrm{yr}^{-1}$. Borges et al. (2005) compiled flux data for upwelling regions around the world and reported an average annual flux of $0.11 \mathrm{~mol} \mathrm{C} \mathrm{m}^{-2} \mathrm{yr}^{-1}$. The results obtained in the present study are within the range of previously published $\mathrm{CO}_{2}$ flux values. Our findings show the large temporal variability of $\mathrm{CO}_{2}$ fluxes in a coastal area characterized by upwelling events.

To fully understand the role that the carbon cycle plays in climate change, other carbon compounds that act as greenhouse gases, such as methane $\left(\mathrm{CH}_{4}\right)$ and chlorofluorocarbons, have to be studied. Large fluxes of $\mathrm{CH}_{4}$ from the sea to the atmosphere have recently been reported. For example, oversaturation of $\mathrm{CH}_{4}$ (up to $>2000 \%$ ) in Ballenas Channel waters (Gulf of California) suggests that the channel is a significant source of atmospheric $\mathrm{CH}_{4}$, with fluxes as high as $3.4 \mu \mathrm{mol}$ $\mathrm{CH}_{4} \mathrm{~m}^{-2} \mathrm{~d}^{-1}$ (Macías-Zamora et al. 2013).

\section{ACKNOWLEDGMENTS}

This study was supported by the National Council for Science and Technology (CONACYT, Mexico, projects SEP-2004-CO1-45813/A1 and CB-2011-01-167361). The first author acknowledges receipt of a postgraduate scholarship from CONACYT. F Ponce participated in the elaboration of the figures.

English translation by Christine Harris.

\section{REFERENCES}

Álvarez-Borrego J, Álvarez-Borrego S. 1982. Temporal and spatial variability of temperature in two coastal lagoons. CalCOFI Rep. 23: $188-197$.

Arthun M, Bellerby RGJ, Omar AM, Schrum C. 2012. Spatiotemporal variability of air-sea $\mathrm{CO}_{2}$ fluxes in the Barents Sea, as determined from empirical relationships and modeled hydrology. J. Mar. Syst. 98-99: 40-50.

http://dx.doi.org/10.1016/j.jmarsys.2012.03.005

Bates NR, Mathis JT, Jeffries MA. 2011. Air-sea $\mathrm{CO}_{2}$ fluxes on the Bering Sea Shelf. Biogeosciences 8: 1237-1253. http://dx.doi.org/10.5194/bg-8-1237-2011

Borges AV, Delille B, Frankignoulle M. 2005. Budgeting sinks and sources of $\mathrm{CO}_{2}$ in the coastal ocean: Diversity of ecosystems counts. Geophys. Res. Lett. 32(14): L14601. http://dx.doi.org/10.1029/2005GL023053

Boutin J, Etcheto J, Dandonneau Y, Bakker DCE, Feely RA, Inoue HY, Ishii M, Ling RD, Nightingale PD, Metzl N, Wanninkhof R. 1999. Satellite sea surface temperature: A powerful tool for interpreting in situ $\mathrm{pCO}_{2}$ measurements in the equatorial Pacific Ocean. Tellus 51B(2): 490-508. http://dx.doi.org/10.1034/j.1600-0889.1999.00025.x ya que los valores más altos de $\mathrm{pCO}_{2}$ y flujos de $\mathrm{CO}_{2}$ en primavera coincidieron con las temperaturas más bajas $\left(\leq 14{ }^{\circ} \mathrm{C}\right)$ y una salinidad cercana a 34 . Estas condiciones suceden debido a que el núcleo de la CC que transporta ASA de relativa baja salinidad $(<34)$ hacia el Ecuador, se localiza muy cerca de la costa en la época de primavera en nuestra región (Linacre 2010). Según Durazo et al. (2010), la única masa de agua registrada frente a Ensenada en 2009 fue ASA. La influencia de ASA es máxima durante primavera, en la época de surgencias cuando los vientos del noroeste son más intensos en la región (Pérez-Brunius et al. 2007). En el segundo escenario, la zona costera puede ser neutral o un sumidero débil. En nuestra región, la localidad costera se comportó como un sumidero entre septiembre y enero.

Chávez et al. (2007) mencionan que, en promedio anual, las costas del Pacifico y en general las zonas en latitudes cercanas a los $30^{\circ} \mathrm{N}$ suelen comportarse como una fuente de $\mathrm{CO}_{2}$ a la atmósfera, mientras que las zonas por arriba de $40^{\circ} \mathrm{N}$ se comportan como sumideros. Para las aguas adyacentes a la península de Baja California, De la Cruz-Orozco et al. (2010) reportaron un flujo neto anual de $0.41 \mathrm{~mol} \mathrm{C} \mathrm{m}^{-2}$ año-1 y Hernández-Ayón et al. (2010) reportaron, a partir de datos históricos de $\mathrm{pCO}_{2}$, un flujo neto anual de $0.97 \mathrm{~mol} \mathrm{C} \mathrm{m}^{-2}$ año ${ }^{-1}$. Borges et al. (2005) hicieron una recopilación de datos de flujos en zonas de surgencias del mundo y reportaron un flujo anual promedio de $0.11 \mathrm{~mol} \mathrm{C} \mathrm{m}^{-2}$ año-1 $^{-1}$. Tal como se puede apreciar, los resultados del presente estudio están dentro del rango de valores de flujos de $\mathrm{CO}_{2}$ reportados anteriormente. Este estudio muestra la gran variabilidad temporal que pueden presentar los flujos de $\mathrm{CO}_{2}$ en una zona costera caracterizada por eventos de surgencias.

La aplicación de esta información para dilucidar el papel del ciclo del carbono en el cambio climático sólo será completa si se realizan estudios de otros compuestos de carbono que actúan como gases de invernadero, tales como el metano $\left(\mathrm{CH}_{4}\right)$ y los clorofluorocarbonos. Recientemente se han reportado flujos grandes de $\mathrm{CH}_{4}$ del mar a la atmósfera. Por ejemplo, la sobresaturación de $\mathrm{CH}_{4}$ (hasta $>2000 \%$ ) en las aguas del canal de Ballenas (golfo de California) sugiere que el canal es una fuente significativa de $\mathrm{CH}_{4}$ hacia la atmósfera, con flujos tan grandes como $3.4 \mu \mathrm{mol} \mathrm{CH}_{4} \mathrm{~m}^{-2} \mathrm{~d}^{-1}$ (MacíasZamora et al. 2013).

\section{Agradecimientos}

Este estudio fue financiado por el Consejo Nacional de Ciencia y Tecnología (CONACYT, México) bajo los proyectos SEP-2004-CO1-45813/A1 y CB-2011-01-167361. El primer autor contó con una beca de CONACYT durante su estancia en el posgrado del CICESE. F Ponce ayudó en la elaboración de las figuras. 
Cai WJ, Dai M. 2004. Comment on enhanced open storage of $\mathrm{CO}_{2}$ from shelf sea pumping. Science 306(5701): 1477. http://dx.doi.org/10.1126/science.1102132

Cai WJ, Dai M, Wang Y. 2006. Air-sea exchange of carbon dioxide in ocean margins: A province based synthesis. Geophys. Res. Lett. 33(12): L12603. http://dx.doi.org/10.1029/2006GL026219

Chavez FP, Takahashi T, Cai WJ, Friederich G, Hales B, Wanninkhof R, Feely RA. 2007. Coastal Oceans. In: King AW, Dilling L, Zimmerman GP, Fairman DM, Houghton RA, Marland G, Rose AZ, Wilbanks TJ (eds.), The First State of the Carbon Cycle Report (SOCCR): The North American Carbon Budget and Implications for the Global Carbon Cycle. A Report by the US Climate Change Science Program and the Subcommittee on Global Change Research. National Oceanic and Atmospheric Administration, National Climatic Data Center, Asheville, NC, pp. 149-156.

Chávez de Ochoa MC. 1975. Algunas condiciones de surgencia durante la primavera de 1974, para el área adyacente a Punta Banda Baja California. Cienc. Mar. 2(2): 111-124.

Chen CTA. 2004. Exchanges of carbon in the coastal seas. In: Field CB, Raupach MR (eds.), The Global Carbon Cycle. Island Press, Washington, pp. 341-351.

Chen L, Xu S, Gao Z, Chen H, Zhang Y, Zhan J, Li W. 2011. Estimation of monthly air-sea $\mathrm{CO}_{2}$ flux in the southern Atlantic and Indian Ocean using in situ and remotely sensed data. Remote Sens. Environ. 115(8): 1935-1941. http://dx.doi.org/10.1016/j.rse.2011.03.016

De la Cruz-Orozco ME, Valdez-Holguín JE, Gaxiola-Castro G, Mariano-Matías M, Espinosa-Carreón TL. 2010. Flujos de $\mathrm{CO}_{2}$ océano-atmósfera. In: Gaxiola-Castro G, Durazo R (eds.), Dinámica del Ecosistema Pelágico frente a Baja California 1997-2007. SEMARNAT, INE, CICESE y UABC, pp.165-180.

Durazo R, Baumgartner TR. 2002. Evolution of oceanographic conditions off Baja California: 1997-1999. Prog. Oceanogr. 54(1-4): 7-31 http://dx.doi.org/10.1016/S0079-6611(02)00041-1

Durazo R, Ramírez-Manguilar AM, Miranda LE, Soto-Mardones LA. 2010. Climatología de variables hidrográficas. In: GaxiolaCastro G, Durazo R (eds.), Dinámica del Ecosistema Pelágico frente a Baja California: 1997-2007. SEMARNAT, INE, CICESE y UABC, pp. 25-57.

Friederich GE, Walz PM, Burczynski MG, Chavez FP. 2002. Inorganic carbon in the central California upwelling system during the 1997-1999 El Niño-La Niña event. Prog. Oceanogr. 54(1-4): 185-203. http://dx.doi.org/10.1016/S0079-6611(02)00049-6

Hales B, Takahashi T. 2004. High-resolution biogeochemical investigation of the Ross Sea, Antarctica, during the AESOPS (U.S. JGOFS) Program. Global Biogeochem. Cycles 18(3): GB3006. http://dx.doi.org/10.1029/2003GB002165

Hernández-Ayón JM, Gaxiola-Castro G, Chavez F, Takahashi T, Feely D, Sabine CL, Hales B, Lara-Lara R. 2010. Variabilidad espacial y temporal del flujo de $\mathrm{CO}_{2}$ océano-atmósfera. In: Gaxiola-Castro G, Durazo R (eds.), Dinámica del Ecosistema Pelágico frente a Baja California: 1997-2007. SEMARNAT, INE, CICESE y UABC, pp. 197-208.

Hickey BM. 1979. The California Current system-Hypotheses and facts. Prog. Oceanogr. 8(4): 191-279. http://dx.doi.org/10.1016/0079-6611(79)90002-8

Lara-Lara JR, Álvarez-Borrego S, Small LF. 1980. Variability and tidal exchange of ecological properties in a coastal lagoon. J. Estuar. Coast. Mar. Sci. 11: 613-637.
Linacre L, Durazo R, Hernández-Ayón JM, Delgadillo-Hinojosa F, Cervantes-Díaz G, Lara-Lara JR, Camacho-Ibar V, SiqueirosValencia A, Bazán-Guzmán C. 2010. Temporal variability of the physical and chemical water characteristics at a coastal monitoring observatory: Station ENSENADA. Cont. Shelf Res. 30(16): 1730-1742.

http://dx.doi.org/10.1016/j.csr.2010.07.011

Liu KK, Atkinson L, Chen CTA, Gao S, Hall J, Macdonald RW, Talaue-McManus L, Quiñones R. 2000. Exploring continental margin carbon fluxes on a global scale. EOS Trans. Am. Geophys. Union 81(52): 641-644.

http://dx.doi.org/10.1029/EO081i052p00641-01

Lynn RJ, Simpson JJ. 1987. The California Current System: The seasonal variability of its physical characteristics. J. Geophys. Res. 92(C12): 12947-12966. http://dx.doi.org/10.1029/JC092iC12p12947

Macías-Zamora JV, Castro-Morales K, Burke RA, López-Mariscal M. 2013. Dissolved methane in the sills region of the Gulf of California. Cienc. Mar. 39(2): 119-135. http://dx.doi.org/10.7773/cm.v39i2.2232

Park K. 1965. Total carbon dioxide in sea water. J. Oceanogr. Soc. Japan 21: 54-59.

Pennington JT, Castro CG, Collins CA, Evans WWI, Friederich GE, et al. 2010. The northern and central California Coastal Upwelling System. In: Liu K-K (ed.), Carbon and Nutrient Fluxes in Continental Margins. Springer, Berlin, pp. 29-44.

Pérez-Brunius P, López M, Parés-Sierra A, Pineda J. 2007. Comparison of upwelling indices off Baja California derived from three different data sources. CALCOFI Rep. 48: 204-214.

Rodríguez-Ibáñez C, Álvarez-Borrego S, Marinone SG, Lara-Lara JR. 2013. The Gulf of California is a source of carbon dioxide to the atmosphere. Cienc. Mar. 39(2): 137-150. http://dx.doi.org/10.7773/cm.v39i2.2190

Sarmiento JL, Gruber N. 2006. Ocean Biogeochemical Dynamics. Princeton, New Jersey, 495 pp.

Takahashi T, Sutherland SC, Wanninkhof R, Sweeney C, Feely RA, Chipman DW, Hales B, Friederich G, Chavez F, Sabine C, Watson A, Bakker D, Schuster U, Metzl N, Yoshikawa-Inoue H, Ishiik M, Midorikawak T, Nojiril Y, Kortzingerm A, Steinhoffm T, Hoppema M, Olafsson J, Arnarson T, Tilbrook B, Johannessen T, Olsen A, Bellerby R, Wong C, Delille B, Bates NR, Baar HJW. 2009. Climatological mean and decadal change in surface ocean $\mathrm{pCO}_{2}$, and net sea-air $\mathrm{CO}_{2}$ flux over the global oceans. Deep-Sea Res. (II) 56(8-10): 554-577. http://dx.doi.org/10.1016/j.dsr2.2008.12.009

Thomas WH. 1966. On denitrification in the northeastern tropical Pacific Ocean. Deep-Sea Res. 13(6): 1109-1114. http://dx.doi.org/10.1016/0011-7471(66)90702-9

Thomas H, Bozec Y, Elkalay K, Baar HJW. 2004. Enhanced open ocean storage of $\mathrm{CO}_{2}$ from shelf sea pumping. Science 304(5673): 1005-1008. http://dx.doi.org/10.1126/science.1095491

Torres R, Turner D, Rutllant J, Sobarzo M, Antezana T, González HE. 2002. $\mathrm{CO}_{2}$ outgassing off central Chile (31-30 $\left.\mathrm{S}\right)$ and northern Chile $\left(24-23^{\circ} \mathrm{S}\right)$ during austral summer 1997: The effect of wind intensity on the upwelling and ventilation of $\mathrm{CO}_{2}$ rich waters. Deep-Sea Res. 49: 1413-1429. http://dx.doi.org/10.1016/S0967-0637(02)00034-1

Wanninkhof R, McGillis W. 1999. A cubic relationship between air-sea $\mathrm{CO}_{2}$ exchange and wind speed. Geophy. Res. Lett. 26(13): 1889-1892. http://dx.doi.org/10.1029/1999GL900363

Wanninkhof R, Park GH, Takahashi T, Sweeney C, Feely R, Nojiri Y, Gruber N, Doney SC, McKinley GA, Lenton A, Le-Quére C, Heinze C, Schwinger J, Graven H, Khatiwala S. 2012. Global 
ocean carbon uptake: Magnitude, variability and trends. Biogeosciences 9(8): 10961-11012.

http://dx.doi.org/10.5194/bgd-9-10961-2012

Zhu Y, Shang S, Zhai W, Dai M. 2009. Satellite-derived surface water $\mathrm{pCO}_{2}$ and air-sea $\mathrm{CO}_{2}$ fluxes in the northern South China Sea in summer. Prog. Nat. Sci. 19(6): 775-779.

http://dx.doi.org/10.1016/j.pnsc.2008.09.004
Zirino A, Hernández-Ayón JM, Fuhrmann RA, Álvarez-Borrego S, Gaxiola-Castro G, Lara-Lara JR, Bernstein RL. 1997. Estimate of surface $\mathrm{pCO}_{2}$ in the Gulf of California from underway $\mathrm{pH}$ measurements and satellite imagery. Cienc. Mar. 23(1): 1-22.

Received October 2014, accepted May 2015. 